\title{
REKONSTRUKSI SYSTEM PERIZINAN DALAM PENGELOLAAN PERTAMBANGAN DI INDONESIA BERBASIS NILAI KEADILAN
}

A. Heru Nuswanto, Muhammad Junaidi, , Amri P. Sihotang,

\begin{abstract}
ABSTRAK
Salah satu persoalan yang mengemuka dalam sektor pertambangan adalah masalah perizinan. Dalam praktiknya, izin usaha pengelolaan pertambangan banyak mengalami dilema baik itu dari segi pertentangan peraturan perundangundangan yang belum maksimal dilaksanakan, atau yang lebih parah lagi adalah pertentangan dari masyarakat yang menolak diterbitkannya suatu izin pertambangan. Kondisi inilah yang kemudian dapat menjadi kesimpulan jika terjadi maka pertambangan tidak lagi menjadi daya dukung kesejahteraan, akan tetapi menjadi faktor konflik yang terjadi baik konflik tersebut berbentuk horizontal maupun konflik secara fertikal.

Dalam penelitian, menggunakan pendekatan yuridis normatif. Spesifikasi penelitian yang digunakan dalam penelitian ini adalah diskriptif analitis. Sumber data yang akan membantu dalam penelitian yaitu sumber data sekunder. Sedangkan Metode analisis yang digunakan adalah dengan analisis data secara kualitatif.

Undang-Undang Nomor 23 tahun 2014 tentang Pemerintah Daerah disebutkan dalam Pasal 14 ayat (3) bahwa Urusan Pemerintahan bidang energi dan sumber daya mineral sebagaimana dimaksud pada ayat (1) yang berkaitan dengan pengelolaan minyak dan gas bumi menjadi kewenangan Pemerintah Pusat. Sebelumnya izin pertambangan di berikan pada pemerintah daerah (kabupaten/kota). Pada saat izin pertambangan diberikan ke wenangan oleh pemerintah daerah kota atau kabupaten menujukkan kondisi yang cukup banyak terjadinya konflik.

Desain regulasi terhadap pengelolaan pertambangan pada khususnya izin pertambangan harus mengedepankan semangat dari perundang-undangan yang dibuat. Semangat yang dibuat tentunya tidak terlepas dari esensi yang terkandung dalam muatan konsep pembangunan berkelanjutan dengan berpatokan pada aspek pembangunan yang dilakukan pada saat ini tidak boleh mengesampingkan pada upaya pembangunan pada masa yang akan datang dengan menititekankan keseimbangan ekonomi, ekologi dan social. Hal tersebut menjadi pertimbangan mutlak karena sudah semestinya hukum harus bersifat sebagai alat perubahan ke arah masyarakat yang bersifat dinamis. Hal tersebut dengan mempertimbangkan bahwa hukum dijalankan sesuai dengan kebutuhan atas adanya kepastian sesuai dengan keinginan dan harapan masyarakat.
\end{abstract}

Kata kunci : Perizinan, Pertambangan dan Nilai Keadilan

\section{ABSTRACT}

One issue raised hearts the mining sector is a problem Licensing. In practice, the mining business license management many have a dilemma both in terms of conflict of laws and regulations which are set maximum executed, or what's worse is opposition from society resist the issuance of a mining license. This condition can be roomates are being conclusion if not Happen Again Become so mining capability welfare, but become factors conflicts the conflict good happens shaped operates horizontally or vertically conflict.

In the study, using normative juridical approach. Specifications research used hearts singer is descriptive analytical study. Data source that will help hearts namely research secondary data sources. While the method of analysis used is qualitative data analysis Operate.

Act No. 23 of 2014 about hearts Local Government mentioned Article 14 paragraph (3) that the Government Affairs Division as energy and Mineral Resources revoked ON paragraph (1) relating to the management of oil gas and earth become the authority of the Central Government. Previous mining license given at Local Government (district/city). On When mining license may be authorized by the local government or city districts showed sufficient condition many of the conflicts.

Design regulations Against Mining Management Mining License Must on particularly emphasizes the spirit From legislation Made. Made spirit certainly not be separated from the essence Contained Payload hearts concept of Sustainable development by based on the aspects development that do currently not allowed to override on the future development efforts coming with emphasize Balance Economy, ecology and social. It is the Absolute Being because Considerations Must be legal It stands as a tool change all Directions, 'What is dynamic society. It is considered that the law is executed with the Needs Appropriate their differences Certainty In accordance with the wishes and expectations society.

Keywords : Licensing, Mining and Justice Value 


\section{PENDAHULUAN}

Madzhab neoklasik sangat percaya bahwa kebebasan pasar prasarat penting bagi tumbuh suburnya kapitalisme. Dalam kerangka itu kebijakan Negara harus diarahkan untuk melindungi kebebasan pasar. Berdasarkan argument itu, Negara merancang dan memperkenalkan sejumlah kebijakan seperti deregulasi dan privatisasi. Umpamanya pemerintah amerika serikat semasa Ronald Reagen banyak melahirkan kebijakan deregulasi yang mendorong pertumbuhan ekonomi amerika serikat, sedangkan Margaret Theacher sangat terkenal kepeloporannya dalam hal kebijakan privatisasi BUMN di Inggris. Semua kebijakan tersebut bertujuan mengurangi peran Negara sekaligus menyerahkan aktivitas ekonomi kepada pasar. Negara hanya bertindak sebagai regulator. ${ }^{1}$

Posisi Negara bertindak sebagai regulator artinya Negara sebagai pengendali agar tujuan dari aktifitas ekonomi dapat dilaksanakan secara maksimal untuk kesejahteraan masyarakat. Fungsi dari Negara tersebut seperti yang dikatakan oleh John Austin hukum merupakan sebuah perintah dari penguasa, dan hukum secara tegas dipisahkan dari moral. Hakekat dari semua hukum adalah perintah (command), yang dibuat oleh penguasa yang berdaulat yang ditujukan kepada yang diperintah dengan disertai sanksi apabila perintah itu dilanggar. ${ }^{2}$

Upaya inilah yang kemudian terealisasikan melalui proses kehadiran adanya regulasi yang dibuat oleh negara-negara yang salah satunya pada aspek peraturan pertambangan. Data statistik pengelolaan pertambangan di Indonesiasebagai berikut :

Table 1.1

Produksi Bahan Bakar Minyak 1996-2011

\begin{tabular}{|c|c|c|c|}
\hline Tahun & $\begin{array}{c}\text { Premium } \\
\text { (barel) }\end{array}$ & $\begin{array}{c}\text { Pertamax } \\
\text { (barel) }\end{array}$ & $\begin{array}{c}\text { Pertamax } \\
\text { Plus (barel) }\end{array}$ \\
\hline 1996 & $60,815,000$ & - & - \\
\hline 1997 & $63,373,000$ & - & - \\
\hline 1998 & $59,403,000$ & - & - \\
\hline 1999 & $62,450,271$ & - & - \\
\hline
\end{tabular}

\footnotetext{
${ }^{1}$ As'ad Said Ali, 2009, Negara Pancasila Jalan Kemaslahatan Berbangsa, pustaka LPES, Jakarta, hlm 268

2 Teori Hukum Positivisme Analitis-John Austin, diunduh pada tanggal 01 September 2015 http://gurupknmh.blogs pot.com
}

\begin{tabular}{|c|c|c|c|}
\hline 2000 & $69,243,864$ & - & - \\
\hline 2001 & $66,533,951$ & - & - \\
\hline 2002 & $68,975,134$ & - & - \\
\hline 2003 & $64,367,803$ & $2,282,000$ & 617,000 \\
\hline 2004 & $70,260,076$ & $3,010,000$ & 300,000 \\
\hline 2005 & $71,013,010$ & $1,699,754$ & 431,836 \\
\hline 2006 & $71,822,000$ & $1,631,764$ & 414,563 \\
\hline 2007 & $71,337,000$ & $2,754,000$ & 951,000 \\
\hline 2008 & $72,404,000$ & $1,523,000$ & 387,000 \\
\hline 2009 & $72,799,000$ & $2,050,000$ & 647,000 \\
\hline 2010 & $66,820,000$ & $3,301,000$ & 668,000 \\
\hline 2011 & $64,460,000$ & $2,446,000$ & 736,000 \\
\hline
\end{tabular}

Sumber : Kementrian Energi dan Sumber Daya Mineral (ESDM)

Berdasarkan data di atas dapat dikatakan bahwa potensi dumber daya alam Indonesia dari sektor petyambangan cukup memiliki posisi yang startegis dalam upaya direalisasikan untuk pendukung kesejahteraan negara. Namun di berbagai negara seperti halnya di Indonesia, adanya pertambangan tidak menjadi persoalan yang mendukung kesejahteraan, akan tetapi malah menimbulkan konflik dalam sebuah negara.

Salah satu persoalan yang mengemuka dalam sektor pertambangan adalah masalah perizinan. Dalam praktiknya, izin usaha pengelolaan pertambangan banyak mengalami dilema baik itu dari segi pertentangan peraturan perundang-undangan yang belum maksimal dilaksanakan, atau yang lebih parah lagi adalah pertentangan dari masyarakat yang menolak diterbitkannya suatu izin pertambangan. Kondisi inilah yang kemudian dapat menjadi kesimpulan jika terjadi maka pertambangan tidak lagi menjadi daya dukung kesejahteraan, akan tetapi menjadi faktor konflik yang terjadi baik konflik tersebut berbentuk horizontal maupun konflik secara fertikal.

Beberapa persoalan yang mengemuka dapat dicontohkan seperti halnya terjadi di Sukolilo Pati terkait ijin pertambangan prabrik semen. Ijin mendirikan pabrik semen gresik yang ingin melakukan penambangan (eksploitasi) batu kapur yang ada di pegunungan Kendeng, sudah didapatkan utamanya dari pemerentah daerah setempat. Persoalan yang muncul kemudian adalah adanya penolakan dari masyarakat dan beberapa lembaga swadaya masyarakat yang ada di Pati Jawa 
Tengah yang mereka memiliki perspektif bahwa adanya pertambangan akan merusak lingkungan.

Persoalan ini cukup menarik untuk dikaji, mengingat secara prinsipil jika kita kembali pada kontitusi (Undang-Undang Dasar dan Pancasila) dalam pengelolaan pertambangan atau kekayaan alam tidak boleh bertentangan dengan tujuan kepentingan masyarakat. Maka sudah semestinya sektor pertambangan harus dimaksimalkan utamanya dengan mengantisipasi masalah-masalah yang terjadi yaitu adalah pada sektor pemberian izin.

\section{METODE PENELITIAN}

Penelitian dilakukan menggunakan pendekatan yuridis normatif. Pendekatan yuridis normatif adalah pendekatan yang digunakan untuk melihat aspek-aspek hukum dalam peraturan perundang yang berfungsi sebagai penunjang untuk megindentifikasikan dan mengklarifikasi temuan bahan hukum bagi kepentingan penelitian.

Spesifikasi penelitian dengan metode diskriptif yang diharapkan mampu menjadi bahan pendukung untuk menggambarkan setting sosial yang terjadi atas konsep dan masalah-masalah yang ada dalam izin pertambangan. Sedangkan analitis adalah sebagai bentuk upaya untuk melakukan analisis secara komperhensif terhadap masalah pokok dalam hambatab-hambatan yang terjadi dan sistem perizinan yang ideal dalam pengelolaan pertambangan di Indonesiaberbasis nilai keadilan.

Dalam mendukung prose situ semua, maka penelitian dilakukan dengan dukungan sumber data yang akan membantu dalam penelitian yaitu sumber data sekunder. Sumber data sekunder yaitu sumber data berupa peraturan perundang-undangan, buku-buku, tulis-tulisan, koran, majalah dan sumber data tertulis lainnya yang diperoleh dari hasil studi pustaka, studi dokumentasi dan studi arsip.

Setelah data dikumpulkan, maka dilakukan analisis data. Metode analisis yang digunakan adalah dengan analisis data secara kualitatif. Dalam menjalankan proses analisis data kualitatif prosesnya dijalankan sebagai berikut ;

a. Mencatat yang menghasilkan catatan lapangan, dengan hal itu diberi kode agar sumber datanya tetap ditelusuri.

b. Mengumpulkan, memilah, mengklasifikasikan, mensintesiskan, membuat ikhtisar dan membuat indeksnya. c. Berpikir, dengan jalan membuat agar kategori data itu mempunyai makna, mencari dan menemukan pola dan hubungan-hubungan, dan temuan-temuan umum ${ }^{3}$.

\section{HASIL DAN PEMBAHASAN}

Dalam lampiran Undang-Undang Nomor 23 tahun 2014 tentang Pemerintahan Daerah, matriks pembagian urusan pemerintahan konkuren antara pemerintah pusat dan daerah provinsi dan daerah kabupaten/kota yang dalam hal ini adalah pembagian urusan pemerintahan bidang energi dan sumber daya mineral diantaranya sebagai berikut :

Table 1.4

Pembagian Urusan Terkaitn Ixin Pertambangan Sesuai Dengan lampi ran Undang-Undang No 23 Tahun 2014 tentang Pemerintah Daerah

\begin{tabular}{|l|l|}
\hline PemerintahPusat & $\begin{array}{l}\text { Pemerintah Daerah } \\
\text { Provinsi }\end{array}$ \\
\hline
\end{tabular}

a. Penetapan wilayah a. Penetapan wilayah izin pertambangan sebagai usaha pertambangan bagian dari rencana tata mineral bukan logam ruang wilayah nasional, yang terdiri atas wilayah usaha pertambangan, wilayah pertambangan rakyat dan wilayah pencandangan Negara serta wilayah usaha pertambangan khusus.

b. Penetapan wilayah izin usaha pertambangan mineral logam dan batu bara serta wilayah izin usaha pertambangan khusus. dan batuan dalam 1 (satu) daerah provinsi dan wilayah laut sampai dengan 12 mil.

b. Penerbitan izin usaha pertambangan mineral logam dan batu bara dalam rangka penanaman modal dalam negeri pada wilayah izin usaha pertambangan daerah yang berada dalam 1 (satu) daerah provinsi termasuk wilayah laut sampai dengan12 mil laut. usaha pertambangan mineral bukan logam dan batuan lintas daerah provinsi dan wilayah laut lebih dari 12 mil.

c. Penerbitan izin usaha pertambangan mineral bukan logam dan batuan dalam rangka penanaman modal dalam negeri pada wilayah izin usaha pertambangan yang berada dalam1 (satu) daerah provinsi termasuk wilayah laut sampai dengan 12 mil laut.

${ }^{3}$ Lexi J. Moleong, 2007, Metodologi Penelitian Kualitatif, Rosda, Bandung, hlm. 248. 
Sumber : lampiran UU No 23 Tahun 2014 tentang Pemerintah Daerah

Sebagai upaya untuk memaksimalkan keadilan, maka dalam Undang-Undang Nomor 23 tahun 2014 tentang Pemerintahan Daerah yang dalam hal ini pada Pasal (5) disebutkan bahwa Daerah kabupaten/kota penghasil dan bukan penghasil mendapatkan bagi hasil dari penyelenggaraan Urusan Pemerintahan sebagaimana dimaksud pada ayat (1). Disini jelas daerah tetap mendapatkan hasil manfaat pertambangan yang ada di daerahnya, namun kapasitas pemerintah (pusat dan provinsi) terkait pemberian izin hanya sebagai bentuk menjaga system ekologi yang berbasiskan pembangunan berkelanjutan dengan berorientasi pada konsepkonsep yang berbasiskan ekonomi, lingkungan dan sosial.

Berbeda dengan konsep sebelumnya. Izin usaha pertambangan diberikan oleh pemerintah daerah yang dalam hal ini yaitu kabupaten atau kota. Namun dalam pelaksanaannya banyak terjadi permasalahan diantaranya konflik antara pemerintah daerah dan masyarakat terkait izin pertambangan. Data dar HuMa menujukkan bahwa

HuMa mencatat konflik berlangsung di 98 kota/kabupaten di 22 provinsi. Yang memprihatinkan, luasan area konflik mencapai 2.043.287 hektar atau lebih dari 20 ribu $\mathrm{km} 2$. Luasan ini setara dengan separoh luas Provinsi Sumatera Barat. Secara kuantitas, konflik yang didokumentasikan HuMa ini hanya potret permukaan saja. Bisa dibayangkan jika semua konflik berhasil diidentifikasi jumlah dan luasannya yang pasti akan jauh lebih besar. Dari 22 provinsi konflik yang didokumentasikan HuMa, tujuh provinsi di antaranya memiliki konflik paling banyak, yakni Aceh, Banten, Jawa Barat, Jawa Tengah, Kalimantan Barat, Kalimantan Tengah dan Sumatera Utara.

Kondisi yang dipaparkan HuMa tersebut diperjelas dengan uraian table sebagai berikut :
Table 1.4

Provinsi dengan Konflik Terbanyak

\begin{tabular}{|c|l|c|c|}
\hline No & \multicolumn{1}{|c|}{ Provinsi } & Jumlah kasus & $\begin{array}{c}\text { Luas Lahan } \\
\text { (hektar) }\end{array}$ \\
\hline 1 & Kalimantan Tengah & 67 kasus & 254.671 \\
\hline 2 & Jawa Tengah & 36 kasus & 9.043 \\
\hline 3 & Sumatera Utara & 16 kasus & 114,385 \\
\hline 4 & Banten & 14 kasus & 8,207 \\
\hline 5 & Jawa Barat & 12 kasus & 4,422 \\
\hline 6 & Kalimantan Barat & 11 kasus & 551,073 \\
\hline 7 & Aceh & 10 kasus & 28.522 \\
\hline
\end{tabular}

Berdasarkan data di atas, kondisi konflik pertambangan pada saat izin pertambangan diberikan kewenangan oleh pemerintah daerah kota atau kabupaten menujukkan kondisi yang cukup banyak. Tentunya hal ini menjadi permasalahan yang berarti untuk diselesaikan lebih lanjut. Melalui pertimbangan tersebut maka pemerintah dalam Undang-Undang Nomor 23 tahun 2014 mengubah kapasitas pemerintah daerah kota atau kabupaten dalam menerbitkan ijin untuk selanjutnya diberikan kepada pemerintah daerah Provinsi dan pemerintah pusat.

Berangkat berdasarkan kewenangan dalam Undang-Undang tersebut, saat ini pemerintah provinsi Jawa Tengah melalui dinas ESDM memperketat izin pertambangan. Dinas ESDM Provinsi Jawa Tengah memperketat izin pertambangan termasuk galian C. Sebelum bisa menambang, pengusaha galian $\mathrm{C}$, harus memenuh $\mathrm{i}$ izin wilayah, izin ekplorasi dan izin operasi produksi 5 .

Kedudukan pemberian izin idealnya memang harus menempatkan aspirasi dan prakarsa masyarakat sesuai pada tempatnya. Disini juga dapat disimpulkan menjadi indikator permasalahan pertambangan yang selama ini terjadi dikarenakan kurang adanya dasar dan fakta yang jelas termasuk dalam hal ini daya dukung masyarakat dalam proses mekanisme pemberian izinnya.

Pada pihak lain, Karakteristik the living law dalam pencarian keadilan paripurna sangat penting untuk diperhatikan. Terkait dengan masalah ini

\footnotetext{
${ }^{4}$ Sumber outlock konflik sumberdaya alam dan agrarian 2012 HuMa, Pusat Database dan informasi HuMa 2012

5 Tribun jateng, teguh merasa pemprov seperti tukang cuci piring, selasa 2 februari 2016, hlm 13
} 
perlu ditegaskan pernyataan Muladi bahwa dengan berlakunya ajaran sifat melawan hukum materiil, maka hukum yang hidup mempunyai multiguna, baik sebagai dasar pemidanaan (kalau tidak ada bandingannya dengan hukum positif), sebagai alasan penghapus pidana (alasan pembenar) maupun alasan pemberatan pemidanaan. Hal in i harus dipertimbangkan oleh hakim di pengadilan umum. Hakim harus berani menilai sampai sejauh inana validitas the living law tersebut, apakah merupakan culture yang harus diapresiasi atau merupakan counter culture yang justru harus dianulir. Dalam hal ini peranan Pancasila sebagai margin of appreciation dalam hukum yang hidup di dalam masyarakat menjadi penting ${ }^{6}$.

Desain hukum yang demikian dapat dicontohkan dalam kasus pembatalan izin pabrik semen di Pati yang dikeluarkan oleh bupati pada. Pengadilan Tata Usaha Negara (PTUN) membatalkan Surat Keputusan Bupati Pati Nomor 660.1/4767 tentang izin lingkungan pembangunan pabrik semen dan penambangan.

Hal yang menjadi unsur pertimbangan hakim dalam membuat keputusan adalah unsur aplikasi konsep pembangunan berkelanjutan dalam menyoroti pemberian izin yang dilakukan oleh bupati pati. Mas Ahmad Santosa salah seorang ilmuan yang berkompeten terhadap masalahmasalah yang berkaitan dengan lingkungan hidup mengeindentifikasikan beberapa alasan yang mendasari negara-negara industri maupun negara berkembang seperti halnya Indonesia, menganggap penegakan hukum lingkungan sebagai hal yang penting, ${ }^{7}$ yaitu;

a. Efektifitas hukum

b. Alasan Keadilan

c. Alasan Kredibilitas

d. Alasan Efisiensi Ekonomi

Pada pertimbangan lain keadilan hukum tidak hanya mengacu pada aturan tertulis. Lebih dari itu, ritus-ritus sosial yang ada dalam hukum harus menjadi bahan pertimbangan dalam memberikan putusan izin pertambangan yang sesuai dengan prinsip dan asas keadilan.

Sebagai bahan pertimbangan dalam hal in i dapat dinyatakan bahwa keadilan merupakan faktor

\footnotetext{
${ }^{6}$ Suteki, 2013, Desain Hukum Di Ruang Sosial,Thafa Media, Yogyakarta, hlm 197

7 Arif Hidayat dan Adji Samekto, 2007, Kajian Kritis Penegakan Hukum Lingkungan di era Otonomi Daerah, Badan Penerbit UNDIP, Semarang, hlm 3-4
}

penting bagi alasan keberadaan penegakan hukum. Filosof-filosof Yunani kuno seperti Socrates, Plato, dan Aristoteles menyatakan, tujuan hukum adalah mewujudkan keadilan dan untuk itu penegakan hukum diperlukan. Dalam hal ini, pemikiranpemikiran yang bersumber dan ajaran agama belum begitu kuat. Kuatnya pengaruh agama, dalam pembentukan hukum di masa berikutnya, terjadi karena Kristen dijadikan. sebagai agama bangsa Romawi, semasa Imperium Romawi berkuasa atas sebagian besar daratan Eropa ${ }^{8}$.

Sebagai tambahan lain untuk mencerna keadilan yang sesungguh-sungguhnya, maka hukum harus menempatkan posisi yang netral sesuai perubahan dan bersifat terbuka (konvergance), pemikiran ini salah satunya disampaikan oleh Roscoe Pound. Pemikiran Roscoe Pound sesungguhnya dilatar belakangi oleh pemikiran filosof Perancis Montesquieu dalam bukunya L'Esprit des Lois yang dipandang oleh Roscoe Pound sebagai yang pertama kali menerapkan prinsip-prinsjp fundamental sociological jurist. Di dalam buku tersebut Montesquieu mengemukakan bahwa: "system of law is a living growth and development interralated with the physical and societal movement". Dengan demikian, menurut Montesquieu, sistem hukum hidup dan berkembang sesuai dengan perubahanperubahan sosial. Dan latar belakang pemikiran Montesquieu inilah, maka kita bisa memahami pandangan Roscoe Pound bahwa tugas hukum adalah sebagai alat untuk melakukan rekayasa sosial demi kepentingan kesejahteraan bersama. Pemikiran yang mendorong perhatian terhadap keterkaitan hukum dengan perubahan sosial (yang juga memengaruhi pemikiran Roscoe Pound) adalah pemikiran Rudolf von Jhering (1818-1892). Jhering menolak keyakinan yang dibangun mazhab sejarah sebagaimana dibangun Von Savigny (17791861). Pada tahun 1852, Jhering menolak pendapat Von Savigny tentang hukum Romawi. Menu rut Von Savigny, seluruh hukum Romawi merupakan refleksi jiwa bangsa Romawi, dan karena itulah maka hukum Romawi merupakan hukum nasional9.

Menjadi pertimbangan di atas memang sudah semestinya hukum harus bersifat sebagai alat perubahan ke arah masyarakat yang bersifat dinamis. Hal tersebut dengan pertimbangan bahwa

\footnotetext{
${ }^{8}$ Fx Adji Samekto, 2013, Hukum Dalam Lintasan Sejarah, Indept Publishing, hlm 2

${ }^{9}$ Fx Adji Samekto, ibid, hlm 71
} 
hukum dijalankan sesuai dengan kebutuhan atas adanya kepastian sesuai dengan keinginan dan harapan masyarakat.

Oleh karena itu sebagai dasar pemberian izin pertambangan tentunya selain ketentuan normatif yang akan dijadikan dasar pembuatan, maka instrument asas juga menjadi salah satu indikator utama pertimbangan oleh pemerintah dalam mengeluarkan izin pertambangan. Dalam Undang-Undang Republik Indonesia Nomor 12 Tahun 2011 tentang Pembentukan Peraturan Perundang-Undangan yang dalam hal ini peneliti dapat menjadi bagian dari aspek izin pertambangan, Pasal 5 dalam membentuk Peraturan Perundangundangan menyebutkan harus dilakukan berdasarkan pada asas Pembentukan Peraturan Perundang-undangan yang baik.

Disini dapat disimpulkan bahwa desain regulasi terhadap pengelolaan pertambangan pada khususnya izin pertambangan harus mengedepankan semangat dari perundangundangan yang dibuat. Semangat yang dibuat tentunya tidak terlepas dari esensi yang terkandung dalam muatan konsep pembangunan berkelanjutan dengan berpatokan pada aspek pembangunan yang dilakukan pada saat ini tidak boleh mengesampingkan pada upaya pembangunan pada masa yang akan datang dengan menititekankan keseimbangan ekonomi, ekologi dan sosial.

\section{KESIMPULAN}

Undang-Undang Nomor 23 tahun 2014 tentang Pemerintah Daerah disebutkan dalam Pasal 14 ayat (3) bahwa Urusan Pemerintahan bidang energi dan sumber daya mineral sebagaimana dimaksud pada ayat (1) yang berkaitan dengan pengelolaan minyak dan gas bumi menjadi kewenangan Pemerintah Pusat. Sebelumnya izin pertambangan di berikan pada pemerintah daerah (kabupaten/kota). Pada saat izin pertambangan diberikan kewenangan oleh pemerintah daerah kota atau kabupaten menujukkan kondisi yang cukup banyak terjadinya konflik. Kedudukan pemberian izin idealnya memang harus menempatkan aspirasi dan prakarsa masyarakat sesuai pada tempatnya. Disini juga dapat disimpulkan menjadi indikator permasalahan pertambangan yang selama ini terjadi dikarenakan kurang adanya dasar dan fakta yang jelas termasuk dalam hal ini daya dukung masyarakat dalam proses mekanisme pemberian izinnya.

Sedangkan dalam proses desain regulasi terhadap pengelolaan pertambangan pada khususnya idealnya izin pertambangan harus mengedepankan semangat dari perundangundangan yang dibuat. Semangat yang dibuat tentunya tidak terlepas dari esensi yang terkandung dalam muatan konsep pembangunan berkelanjutan dengan berpatokan pada aspek pembangunan yang dilakukan pada saat ini tidak boleh mengesampingkan pada upaya pembangunan pada masa yang akan datang dengan menititekankan keseimbangan ekonomi, ekologi dan social. Hal tersebut menjadi pertimbangan mutlak karena sudah semestinya hukum harus bersifat sebagai alat perubahan ke arah masyarakat yang bersifat dinamis. Hal tersebut dengan mempertimbangkan bahwa hukum dijalankan sesuai dengan kebutuhan atas adanya kepastian sesuai dengan keinginan dan harapan masyarakat.

\section{DAFTAR PUSTAKA}

Arif Hidayat dan Adji Samekto, 2007, Kajian Kritis Penegakan Hukum Lingkungan di era Otonomi Daerah, Badan Penerbit UNDIP, Semarang

As'ad Said Ali, 2009, Negara Pancasila Jalan Kemaslahatan Berbangsa, pustaka LPES, Jakarta

Fx Adji Samekto, 2013, Hukum Dalam Lintasan Sejarah, Indept Publishing

Lexi J. Moleong, 2007, Metodologi Penelitian Kualitatif, Rosda, Bandung

Sumber outlock konflik sumberdaya alam dan agrarian 2012 HuMa, Pusat Database dan informasi HuMa 2012

Suteki, 2013, Desain Hukum Di Ruang Sosial,Thafa Media, Yogyakarta

Teori Hukum Positivisme Analitis-John Austin, diunduh pada tanggal 01 September 2015 http://gurupknmh.blogspot.com

Tribun jateng, teguh merasa pemprov seperti tukang cuci piring, selasa 2 februari 2016 